\title{
Robust PID Parameter Design for Embedded Temperature Control System Using Taguchi Method
}

\author{
Arata Suzuki Member (Zojirushi Corporation) \\ Kenji Sugimoto Non-member (Nara Institute of Science and Technology)
}

Keywords: embedded temperature control system, PID control, Taguchi's robust design

Embedded temperature control systems are widely used in various fields such as household electric appliances. In such applications, robustness against outside temperature is a crucial issue because of a wide variety of environmental conditions.

Conventional parameter design methods for PID control are not necessarily robust in this regard. On the other hand, if we adjust the parameter according to outside temperature measurement, we need additional sensors to this end, which means a cost-increase and is undesirable in mass-production-type embedded systems such as household electric appliances.

In this paper, we apply Taguchi method to the design of PID control parameter. Taguchi method is widely used in industry, and it is a promising method known in quality engineering (robust design). However, few applications have been found in control engineering so far. In particular, to the best of the authors' knowledge, there has been no report using Taguchi method for robust design of PID control against disturbances.

The authors have performed experiment with an experimental system in order to evaluate the effectiveness of the PID parameter design by Taguchi method (Fig. 1). Output signals by Taguchi method (proposed) and Limit Cycle method (conventional), respectively, are given in Fig. 2 and Fig. 3 for the outside temperatures $5\left[{ }^{\circ} \mathrm{C}\right]$ and $30\left[{ }^{\circ} \mathrm{C}\right]$, for the objective temperature $70\left[{ }^{\circ} \mathrm{C}\right]$. The proposed method results in the difference $0.3\left[{ }^{\circ} \mathrm{C}\right]$ in the steady state, while the conventional method gives $2.4\left[{ }^{\circ} \mathrm{C}\right]$. Therefore the proposed method has turned out to be robust against the change of outside temperature.

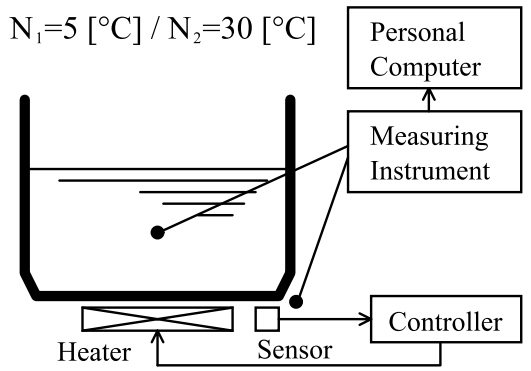

Fig. 1. Experimental System

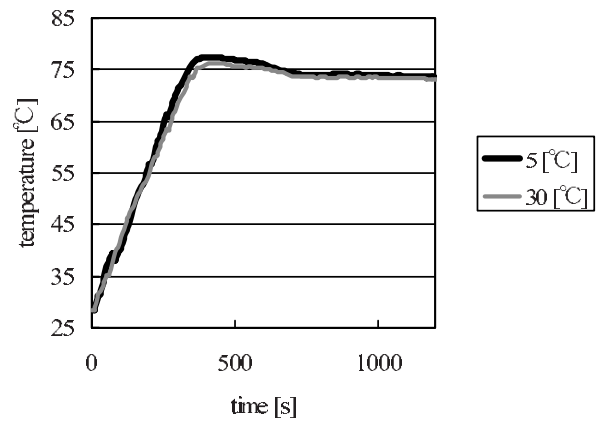

Fig. 2. Output Signals (Taguchi Method)

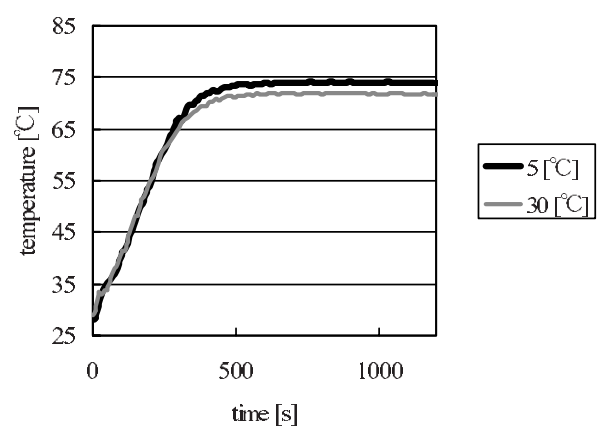

Fig. 3. Output Signals (Limit Cycle Method) 


\title{
タグチメソッドによる組み込み温度制御システムの ロバストPIDパラメータ設計
}

\author{
正 員 鈴木 新* 非会員 杉本 謙二**
Robust PID Parameter Design for Embedded Temperature Control System Using Taguchi Method

Arata Suzuki*, Member, Kenji Sugimoto**, Non-member

\begin{abstract}
This paper proposes a robust PID parameter design scheme using Taguchi's robust design method. This scheme is applied to an embedded PID temperature control system which is affected by outside (room) temperature. The effectiveness of this scheme is verified experimentally with a cooking household appliance.
\end{abstract}

キーワード：組み込み温度制御システム, PID 制御, タグチメソッド

Keywords: embedded temperature control system, PID control, Taguchi's robust design

\section{1. はじめに}

組み込み温度制御システムは, 調理家電や感熱印字プリ ンタなど家庭電化製品として広く利用されている。これら の組み込み温度制御システムの商品価值や品質を決定する 重要な機能として, 温度制御性能があげられる。例えば, 調 理家電の目的は, 調理対象を設定した温度で加熱調理する ことであり，温度制御性能が商品価值を左右する調理の仕 上がりに大きく影響する。

しかし, 組み込み温度制御システムの温度制御性能には 様々な要因が影響を与える。特に, 外気温の変化は調理対 象である被加熱物の温度勾配を変化させ，内部と外表面部 の温度差を大きくするために，調理の仕上がりを悪化させ る。しかし, 外気温の変化は, 寒冷地と温暖地, 季節による 違いなど，客先での使用条件が多岐にわたる組み込み温度 制御システムでは，避けることのできない要因である。外 気温の変化に対応できない商品では, 季節によって調理の 仕上がりが変化し, 消費者からは品質不良として返品され ることになり，商品価值や企業価值を下げることになって しまう。

上述の問題点に対応するため, 外気温を計測し, 外気温 に適した制御パラメータをリアルタイムで選択する方法な

\footnotetext{
*象印マホービン（株）

于 530-8511 大阪市北区天満 1-20-5

ZOJIRUSHI Corporation

1-20-5, Kitaku tenma, Osaka 530-8511

** 奈良先端科学技術大学院大学

T 630-0192 生駒市高山町 8916-5

Nara Institute of Science and Technology

8916-5, Takayama-cho, Ikoma 630-0192
}

ども考えられる。しかし，この方法では温度制御用とは別 に外気温を計測するセンサが必要となる。センサの追加は, 調理家電のような大量生産型の組み込みシステムでは，コ ス卜競争力を低下させるので望ましくない(1)。そこで，七 ンサの追加を必要とせず，外気温に対してロバストな制御 パラメータを持つ固定された制御器の設計ができれば望ま しい。

このような要求に対して, 本研究では温度制御系に多く 用いられている PID 制御のパラメータ設計をタグチメソッ ド(2)によって行う方法を提案する。タグチメソッドは，製 品開発などの設計工学の分野でロバストデザインと呼ばれ る設計手法として様々な適用例 ${ }^{(3)}$ (5) がある。また, PID 制 御は， P, I, Dの 3 種類のパラメータによって制御入力を 決定する非常に簡便な構造を持つ制御手法であり, 制御動 作も分かりやすく, 現場での調整も容易に行えるので広く 実用化されている。また，そのパラメー夕設計法も様々な アプローチによって研究されて扮り, 伝統的な設計法とし て, 限界感度法, ステップ応答法, リミットサイクル法な どがある(の)。これらの方法は, 古典的ではあるが現在でも 多く利用されている。また, 近年はパラメー夕の自動調整 （セルフチューニング）に関する研究なども盛んに行われて いる(7)。

しかし, 上述の古典的な PID パラメータ設計法は, 制御 システムが定常状態では十分な性能を有するが，外乱など の不確かな要因のもとでは制御性能が不十分になる場合も ある。このような外乱に対してロバストな PID 制御系の設 計手法として, 部分的モデルマッチングによる I-PD 制御 法 ${ }^{(8)}$, 特性変動分を考慮した設計法 ${ }^{(9)}$, 複数の混合感度問題 によるロバスト設計法 ${ }^{(10)}$ などが提案されている。これらの 
方法は伝達関数などで表されるモデルをもとに，パラメー 夕変動によってシステムが受ける影響からロバスト性を議 論している。それに対して本研究で提案する方法では, 実 験結果を直接利用して，外気温変化に強いパラメータを統 計的手法から設計することに特徵がある。このようなアプ ローチは, 設計工学の分野だけでなく制御の分野でも有効 であると考えられる。制御の分野に扔けるタグチメソッド の適用例は, ファジー制御に扔いて最適なメンバーシップ関 数などを求める問題に GA と組み合わせて用いた例(11) や, 省エネなどの観点から位置決め時間を最小とする制御パラ メータの設計に用いた例 (12)などがあるが，まだ数が少ない。 また，これらは交互作用のある設計パラメータのために，設 計が煩雑になることを回避する目的でタグチメソッドを適 用しており，本研究のように外乱に対するロバス卜性を得 ることが目的ではない。このように, 本研究で取り上げる 使用環境の変化などの外乱に強い制御システムを設計する というタグチメソッドのロバスト設計を積極的に活用した 例は，筆者らの知る限りない。

以上のように，本研究で提案する制御システムの設計法 では, センサの追加などのハードウェアの変更を行わずに, PID パラメータというソフトゥェアの変更のみで, 使用環 境の変化に対してロバストな組み込み温度制御システムを 設計することが可能となる。提案手法の実証のために，実 機モデルによる実験を行って，その効果を確認した。その 結果, 提案手法によって外気温変化にロバストな組み込み 温度制御システムを実現できた。

\section{2. 背 景}

組み込み温度制御システムの一例として調理家電の構造 を説明し，外気温の変化がどのように被加熱物に影響する のかを説明する。通常, 調理家電は図 1 のような構造をし ている。図 1 から分かるように, センサは内部の調理対象 とは接触していない。使用方法やコストの制約などによっ て，センサが調理対象と接触する構造にはできない。

このように，調理対象の温度を鍋などからの伝熱を通し て間接的に計測する場合，温度センサと調理対象との間に 温度勾配が発生し，正確な調理対象の温度を計測できない。 もし，この温度勾配が一定であれば，補正によって正しい 温度が得られる。しかし, 実際の環境では外気温は様々に 変化する。同様に温度勾配も変化するので，補正だけでは 正確な調理対象の温度を計測することはできない。

調理対象に対する外気温変化の影響は, 簡単な実験から

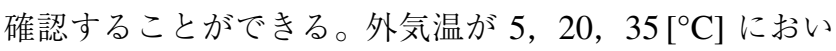
て, $70\left[{ }^{\circ} \mathrm{C}\right]$ で温度制御を行った場合, 外気温が変化するこ とで調理対象の温度がどのように変化するのか確認する。 この実験に打ける外気温と調理対象の温度の散布図を図 2 に示す。このように, 外気温が $5\left[{ }^{\circ} \mathrm{C}\right]$ の場合の調理対象の 平均温度は $74.8\left[{ }^{\circ} \mathrm{C}\right]$, 同梯に外気温が $35\left[{ }^{\circ} \mathrm{C}\right]$ の場合では $71.6\left[{ }^{\circ} \mathrm{C}\right]$ となり, 外気温の変化によって調理対象の温度に $3.2\left[{ }^{\circ} \mathrm{C}\right]$ の差が生じる。なおサンプル数はそれぞれ 8 ケで

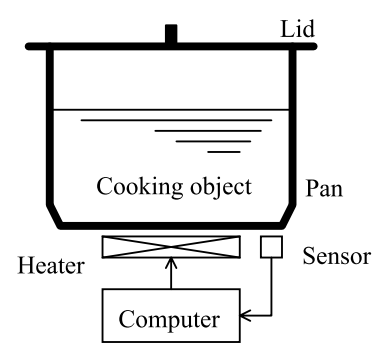

図 1 調理家電の概略構造

Fig. 1. Structure of a Cooking Household Appliance.

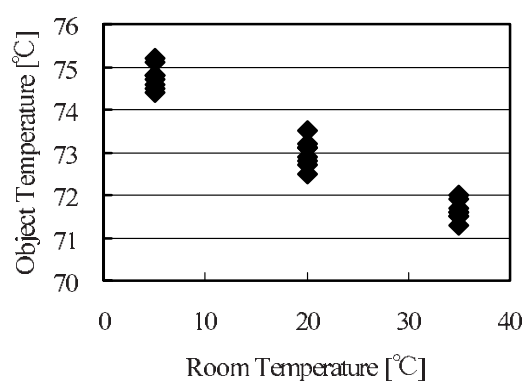

図 2 外気温と調理対象温度との相関図

Fig. 2. Correlation Graph of Room and Cooking Object Temperature.

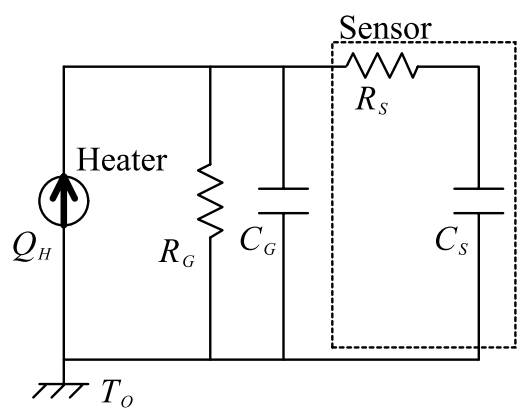

図 3 組み込み温度制御システムの電気回路 モデル

Fig. 3. Electric Circuit Model of Embedded Temperature Control System.

ある。

このような外気温の影響を受けないための対策として, 想定するすべての外気温で制御パラメー夕を求めておき, それらをデータベースに蓄えて, 現在の外気温に応じて参 照する方法 ${ }^{(13)(14)}$ なども利用できる。しかしながら，外気温 をモニ夕するための温度センサを追加する必要があり，大 量生産型の組み込みシステムでは僅かなコストアップが生 産数量分の影響を及ぼすため，望ましい方法ではない。

ここで, 本研究の目的を明確にするために, 組み込み温 度制御システムの電気回路モデル（図 3）を表現し, 外気 温変化の影響を説明する。ここで, ヒー夕の熱入力を $Q_{H}$, 鍋, フ夕等を含む制御対象の外気温に対する熱抵抗と熱容 量をそれぞれ $R_{G}, C_{G}$, 温度センサの熱抵抗と熱容量をそ れぞれ $R_{S}, C_{S}$ とする。温度基準であるグランドは外気温 $T_{O}$ であるので, 外気温の变化が制御対象と温度センサに影 
響を及ぼすことが，図 3 より分かる。このような外気温の 影響を受けにくい固定された制御パラメータの組み合わせ を求めることが，本研究の目的である。

本研究の方法では，七ンサの追加などのハードウェアの 変更は一切行わず，ソフトウェアである制御パラメータの 変更だけで，性能を向上できるのでコストの影響を受けず， 組み込み温度制御システムに適している。

\section{3. パラメータ設計法}

本節では，タグチメソッドの概要と制御システムへ適用 するための方策について示す。

〈3・1〉 タグチメソッド概要タグチメソッドでは, シ ステムが持つ理想的な振る舞いを基本機能と呼び，原点比 例式,

$$
\mathrm{y}=\beta M,
$$

として定義する。 $M$ は信号因子と呼ばれる使用者や設計者 がシステムに対して印加する入力信号であり，y は出力特 性と呼ばれるシステムから得られる出力信号からなるデー 夕である。 $\beta$ はシステムの特性を表す比例定数であり，設 計可能なパラメー夕を持つ。その実現值を $A, B, C, \cdots$ と 表し，制御因子と呼ぶ。制御因子には水準があり，通常夕 グチメソッドで用いられる L18 直交表（表 1) では，2 水準 が 1 個， 3 水準が 7 個，合計で 8 個の制御因子がある。直 交表の利用目的は，実験効率の向上のためである。2 水準 が 1 個， 3 水準が 7 個の組み合わせでは， $2^{1} \times 3^{7}=4,374$ 通りの実験数となるが，それを直交表実験では 18 通りま で削減する。

直交表に制御因子を割り付けて実験を行う。実験結果の 解析は, 計量可能な因子である信号因子 $M$ と計測によって 得られる出力特性 $\mathrm{y}$ から， $\beta$ を求めることから始める。直 交表に従って制御因子の水準を変化させると，制御因子に

\section{表 1 L18 直交表}

Table 1. L18 Orthogonal array.

\begin{tabular}{|r||c|c|c|c|c|c|c|c|}
\hline & A & B & C & D & E & F & G & H \\
\hline \hline 1 & 1 & 1 & 1 & 1 & 1 & 1 & 1 & 1 \\
2 & 1 & 1 & 2 & 2 & 2 & 2 & 2 & 2 \\
3 & 1 & 1 & 3 & 3 & 3 & 3 & 3 & 3 \\
\hline 4 & 1 & 2 & 1 & 1 & 2 & 2 & 3 & 3 \\
5 & 1 & 2 & 2 & 2 & 3 & 3 & 1 & 1 \\
6 & 1 & 2 & 3 & 3 & 1 & 1 & 2 & 2 \\
\hline 7 & 1 & 3 & 1 & 2 & 1 & 3 & 2 & 3 \\
8 & 1 & 3 & 2 & 3 & 2 & 1 & 3 & 1 \\
9 & 1 & 3 & 3 & 1 & 3 & 2 & 1 & 2 \\
\hline 10 & 2 & 1 & 1 & 3 & 3 & 2 & 2 & 1 \\
11 & 2 & 1 & 2 & 1 & 1 & 3 & 3 & 2 \\
12 & 2 & 1 & 3 & 2 & 2 & 1 & 1 & 3 \\
\hline 13 & 2 & 2 & 1 & 2 & 3 & 1 & 3 & 2 \\
14 & 2 & 2 & 2 & 3 & 1 & 2 & 1 & 3 \\
15 & 2 & 2 & 3 & 1 & 2 & 3 & 2 & 1 \\
\hline 16 & 2 & 3 & 1 & 3 & 2 & 3 & 1 & 2 \\
17 & 2 & 3 & 2 & 1 & 3 & 1 & 2 & 3 \\
18 & 2 & 3 & 3 & 2 & 1 & 2 & 3 & 1 \\
\hline
\end{tabular}

対応して $\beta$ も変化する。 $\beta$ の变化は比例定数の傾きの大小, つまり感度の変化である。 $\beta$ の傾きが最も大きい水準の組 み合わせが，最も感度の高い組み合わせになる。

しかし，感度だけではロバスト性に対しては不十分であ る。ロバスト性を考慮するために誤差因子 $N_{r}(r=1, \cdots, R)$ を導入する。誤差因子は，対象とするシステムに影響を及 ぼし，かつ設計者が変更することができない因子である。 本研究の場合では, 外気温の変化が誤差因子になる。外気 温の変化は, 設計対象の温度制御システムに影響を及ぼし, かつ設計者は外気温の変化を止めることはできない。また， 誤差因子は実験数を増やさないために, 複数の誤差因子を出 力特性が大きくなる方向と小さくなる方向に調合し, $N_{1}, N_{2}$ の 2 水準とする方法が一般的である。誤差因子の割り付け は, 制御因子の外側に割り付け，制御因子と誤差因子の交 互作用がすべて検出できる配置（図 4）とする。これによっ て，制御因子が誤差因子によって受ける影響を測ることが できる。

このように制御因子だけでなく誤差因子を配置した実験 結果から $\beta$ を求めると, 同じ制御因子の組み合わせでも, 与 える誤差因子によって $\beta$ の值が少なからず変化することと なる（図 5)。これは, 誤差の不等分散性が繰り返し精度な どによる偶然誤差ではなく，意図的に与えられた誤差因子 による変化（バラツキ）となる。このような誤差因子のも とで $\beta$ を評価すれば，誤差因子に対してロバストな制御因 子の組み合わせを求めることができる。つまり，与える誤 差因子によって $\beta$ が変化しない，または $\beta$ の変化が最も小 さくなる制御因子水準の組み合わせが，誤差因子に対して ロバストな水準の組み合わせである。以上が夕グチメソッ ドの設計の概要である。(タグチメソッドには, 損失関数に

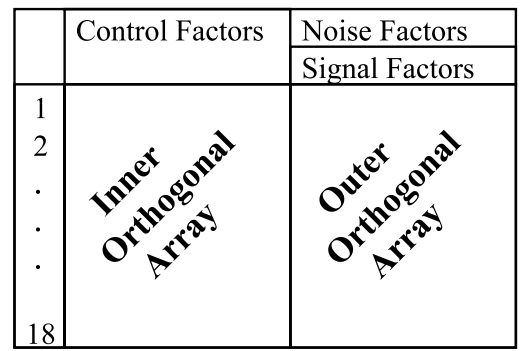

図 4 内側直交表と外側直交表

Fig. 4. Orthogonal Array (Inner and Outer).

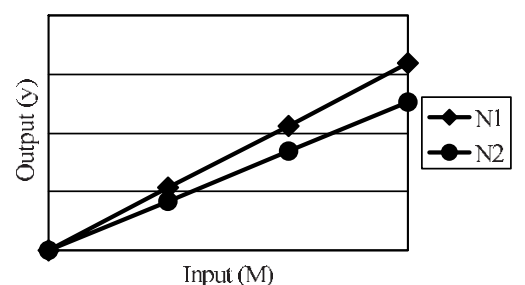

図 5 誤差因子による入出力関係のバラツキ

Fig. 5. Input/Output Relation Data Spread (Affected by Noise Factors). 


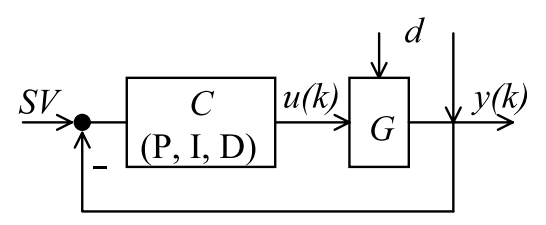

図 6 PID 制御器のブロック線図

Fig. 6. Block Diagram of PID Contoller.

関する項目も含まれているが，本研究においてはパラメー 夕設計のみを利用したので説明も割愛する。）

〈3·2〉 タグチメソッドの制御システムへの適用法＼cjkstart設 計対象の PID 制御器を用いた組み込み温度制御システムの 構成を説明する。制御対象を $G$ ，それを制御するコントロー ラを $C, C$ から $G$ への入力信号を $u(k), G$ から得られる出 力信号を $y(k)$, 目標值を $S V$, 外乱を $d$ とすると, ブロッ ク線図は図 6 のように表される。ここで，kはサンプリン グを表す。

このような温度制御システムにタグチメソッドを適用す るためには, 基本機能 (1) 式で表される原点比例式を定義 しなければならない。信号因子 $M$ は, 設計対象となるシ ステムへの入力信号であるが，プラント $G$ に対する入力信 号 $u(k)$ を信号因子とする方法は用いられない。この理由は 図 6 の制御システムでは, 入力信号 $u(k)$ と内部パラメータ である制御因子，つまり P, I, D の各パラメータとの間に，

$$
\begin{aligned}
u(k+1)= & K_{P} e(k)+K_{I} T_{S} \sum e(k)+ \\
& K_{D} \frac{1}{T_{S}}(e(k)-e(k-1)), \cdot
\end{aligned}
$$

の関係式が成立するためである。ここで， $K_{P}$ は比例ゲイ ン, $K_{I}$ は積分ゲイン,$K_{D}$ は微分ゲイン $T_{S}$ はサンプリン グタイム, $e(k)$ は時刻 $k$ における目標值と出力值との偏差 $e(k)=S V-y(k)$ を表す。(2) 式において, P, I, D パラメー 夕を変化させれば, 入力信号 $u(k)$ も変化する。このように, 信号因子と制御因子が独立に調整ができないので，入力信 号 $u(k)$ を信号因子 $M$ とすることはできない。

ここで，原点に戻り制御システムの理想機能を考える。 制御とは，「注目している対象物に属する注目している動作 が，何らかの目標とする動作になるように，その対象物に 操作を加える行為」(15)である。これは, 本研究で取り扱っ ている定值制御では，どれだけ時間が経過しても，常に目 標值と注目する対象から得られる出力信号が，偏差無く一 致することである。このような理想関係にある場合の経過 時間と出力信号 $y(k)$ を, 基本機能 (1) 式にあてはめる。改 めて経過時間を $T$ として，これを信号因子と考えると $T$ は 線形に増加する。制御の理想関係にあれば出力信号 $y(k)$ が 目標值と一致し定值になるので, $T$ と同じく出力信号 $y(k)$ の積分值も線形に増加する。これは, 出力信号 $y(k)$ の積分 值を出力特性 y とすれば,

$$
\mathrm{y}=\sum y(k)=\beta T,
$$

の関係が成立する。図 6 の制御対象とコントローラを含ん

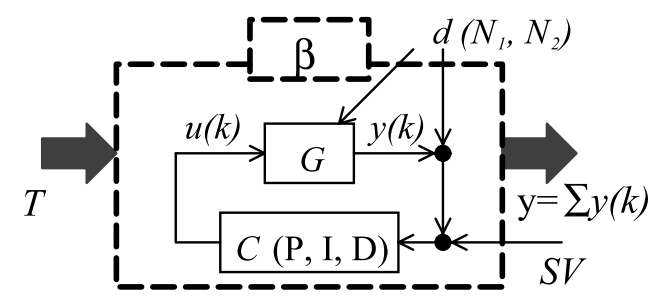

困 7 制御システム設計におけるタグチメソッド 基本機能のブロック線図

Fig. 7. Taguchi's Basic Function for Control System Design.

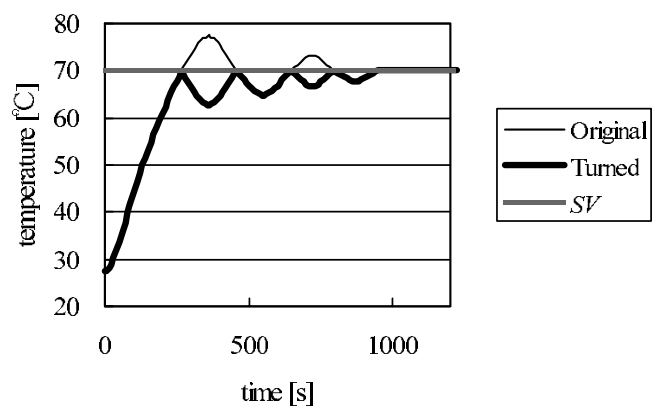

図 8 目標值での折り返し出力信号波形

Fig. 8. Waveform that turned by the $S V$.

表 2 任意の行の実験結果行列

\begin{tabular}{|c|c|c|c|c|}
\hline \multirow{2}{*}{$\begin{array}{l}\text { Noise } \\
\text { Factors }\end{array}$} & \multicolumn{4}{|c|}{ Signal Factors } \\
\hline & $M_{1}$ & $M_{2}$ & $\cdots$ & $M_{N}$ \\
\hline$N_{1}$ & $y_{11}$ & $y_{12}$ & $\cdots$ & $y_{1 N}$ \\
\hline$N_{2}$ & $y_{21}$ & $y_{22}$ & $\cdots$ & $y_{2 N}$ \\
\hline$\vdots$ & & & & \\
\hline$N_{R}$ & $y_{R 1}$ & $y_{R 2}$ & $\ldots$ & $y_{R N}$ \\
\hline
\end{tabular}

Table 2. Matrix of Arbitrary Law's Experimental Result.

だ組み込み温度制御システム全体を, 設計対象のシステム $\beta$ としたことによって，基本機能 (1) 式が成立するように できた（図 7)。このように信号因子を経過時間とする方法 は，化学反応にタグチメソッドを適用する場合 ${ }^{(16)} に よ く$ 用 いられ，タグチメソッドの指針「実験特性の 2 乗が，エネ ルギーに比例すること」にも合致している。

ただし, 出力信号 $y(k)$ をそのまま積分しても正しく評 価できない。これは, 制御システムで通常良く見られるハ ンティング現象を考慮していないためである。ハンティン グのある系では, オーバーシュートによる偏差とアンダー シュートによる偏差が相殺されてしまうので, IAE (Integral Absolute Error) による評価ができないためである。そこで, 二見ら ${ }^{(12)}$ の方法と同じく，次のような対策を行う。

$$
y_{T}(k)=\left\{\begin{array}{lll}
y(k) & \text { if } & y(k) \leq S V \\
S V-(y(k)-S V) & \text { if } & y(k)>S V
\end{array}\right.
$$

このようにして, オーバーシュートを目標值 $S V$ で折り返 して，アンダーシュートと等価にする（図 8)。このような 
対策を行った出力信号を，折り返し出力信号 $y_{T}(k)$ とした。 $y_{T}(k)$ からなる出力特性を $\mathrm{y}_{\mathrm{T}}$ として (3) 式に代入し,

$$
\mathrm{y}_{\mathrm{T}}=\sum y_{T}(k)=\beta T,
$$

を得る。折り返し出力信号 $y_{T}(k)$ では, オーバーシュート とアンダーシュートが, 目標值に対する誤差という点で等 価になるので，IAEによる評価と同じである。以上のよう な方策によって, タグチメソッドが制御システムへ適用可 能となった。

具体的な設計手順について，簡単に記述する。

（1）限界感度法やリミットサイクル法などの従来から 用いられている PID パラメータ設計法によって, パ ラメータを推定する。

（2） P, I, D の各パラメー夕を L18 直交表に割り付け る。割り付け方は，従来手法によって推定した值を 第 2 水準にして，それより小さな值を第 1 水準，大 きな值を第 3 水準とする。

（3）誤差因子を設定し, 外側直交表に割り付ける。䛊 差因子は，現実に考えられる両極端な 2 水準とする。

（4）直交表に基づいて実験を行う。実験結果データ は, 表 2 に示す信号因子と誤差因子の 2 元配置 データとなる。例えば, 誤差因子 $N_{1}, \cdots, N_{R}$, 信号 因子 $M_{1}, \cdots, M_{N}$ として, 直交表の任意の $l$ 行 $(l=$ $1, \cdots, L)$ の実験結果行列 $\mathbf{Y}_{\mathbf{I}}$ は,

$$
\mathbf{Y}_{\mathbf{I}}=\left[\begin{array}{rrrr}
\mathrm{yl}_{11} & \mathrm{yl}_{12} & \cdots & \mathrm{yl}_{1 \mathrm{~N}} \\
\mathrm{yl}_{21} & \mathrm{yl}_{22} & \cdots & \mathrm{yl}_{2 \mathrm{~N}} \\
\vdots & & & \\
\mathrm{yl}_{\mathrm{R} 1} & \mathrm{yl}_{\mathrm{R} 2} & \cdots & \mathrm{yl}_{\mathrm{RN}}
\end{array}\right] .
$$

となる。ここで, 出力特性 $\mathrm{yl}_{\mathrm{rn}}$ は誤差因子 $N_{r}$ のも とでの折り返し信号波形 $y_{T} l_{r}$ から，

$$
\mathrm{yl}_{\mathrm{rn}}=\sum_{k=M_{n-1}}^{M_{n}} y_{T} l_{r}(k),
$$

によって求める $(r=1, \cdots, R \circ n=1, \cdots, N)$ 。 L18 直交表では $l=18$ なので, 実験結果行列 $\mathbf{Y}_{1}$ が 18 個 求まる。

（5）得られた実験結果から最もロバストな制御因子の 水準の組み合わせを求める。ロバスト性の評価は, 通信工学で用いられる SN 比によって行う。SN 比 を $\eta$, 感度を $\beta$, バラツキの大きさ(ノイズによる影 響)を $\sigma$ とすると,

$$
\eta=10 \log \frac{\beta^{2}}{\sigma^{2}},
$$

となる。これらの計算方法の詳細は, 文献 (2) を参照。

（6）ロバストな制御因子の水準の組み合わせで確認実 験を行い, 必要があればパラメータの微調整を行う。

\section{4. 実験}

〈4・1〉 実験方法 本研究で用いた実験装置の概略を 図 9 に示す。鍋の中に被加熱物として水 1,200 [ml] を入れ て, 制御用温度センサ部 $70\left[{ }^{\circ} \mathrm{C}\right]$ で温度制御を行う。水中

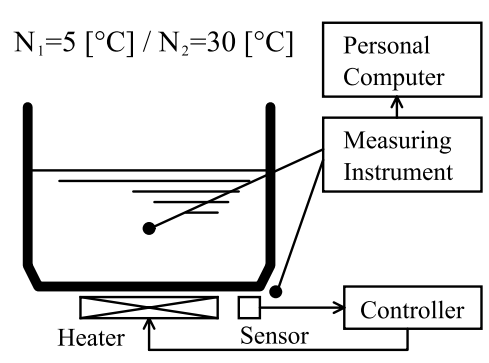

図 9 実験装置

Fig. 9. Experimental System.

表 3 制御因子（P. I. D.），誤差因子（O. T. = Outside temperature $)$ ，信号因子（E. T. = Elapsed time）の一覧

Table 3. A List of Control Factors, Noise Factors, and Signal Factors.

\begin{tabular}{|l||c|c|c|}
\hline \multicolumn{1}{|l||}{ Control } & \multicolumn{3}{|c|}{ Level } \\
\cline { 2 - 4 } Factors & 1 & 2 & 3 \\
\hline A: e & - & - & - \\
B: e & - & - & - \\
C: P & 0.4 & 1.2 & 3.6 \\
D: e & - & - & - \\
E: I & 33.0 & 99.0 & 297.0 \\
F: e & - & - & - \\
G: D & 8.0 & 24.0 & 72.0 \\
H: e & - & - & - \\
\hline \hline Noise & \multicolumn{3}{|c|}{ Level } \\
Factors & 1 & \multicolumn{2}{|c|}{2} \\
\hline$N:$ O. T. & $5\left[{ }^{\circ} \mathrm{C}\right]$ & \multicolumn{2}{|c|}{$30\left[{ }^{\circ} \mathrm{C}\right]$} \\
\hline \hline Signal & \multicolumn{3}{|c|}{ Level } \\
\cline { 2 - 5 } Factors & 1 & 2 & 3 \\
\hline$T:$ E. T. & $400[\mathrm{~s}]$ & $800[\mathrm{~s}]$ & $1200[\mathrm{~s}]$ \\
\hline
\end{tabular}

と制御用温度センサの側近に本研究の制御性能評価用セン サを設置し, 評価用センサから得られるデー夕は温度計測 用インターフェースを備えたパソコンによって計測される。 次に, 直交表実験について示す。L18 直交表にリミット サイクル法で求めた PID パラメータを, 制御因子第 2 水準 に割り付け，それらの 3 分の 1 と 3 倍の值をそれぞれ第 1 水準, 第 3 水準に割り付ける。さらに, 誤差因子として 2 水準, 室温 $5,30\left[{ }^{\circ} \mathrm{C}\right]$ をそれぞれ $N_{1}, N_{2}$ として外側直交 表に割り付ける。同じく外側直交表に信号因子を 3 水準, 経過時間 400，800，1,200 [s] をそれぞれ $M_{1}, M_{2}, M_{3}$ と して割り付けた。制御因子, 誤差因子, 信号因子の一覧を 表 3 に示す。

後は, 直交表に従って実験を行う。18 通りの組合せを誤 差因子数 2 の条件で実験を行うので, 総実験数は 32 となる。

$\langle\mathbf{4} \cdot 2\rangle$ 実験結果 直交表実験の結果から, SN 比とそ のグラフ表現である要因効果図を求めた。SN 比を表 4 に, 要因効果図を図 10 に示す。PID パラメー夕を割り付けた 因子は，C， E， Gであるので，これらの因子の $\mathrm{SN}$ 比を見 ると，C3，E1，G2 が SN 比の高い組み合わせとなる。こ れは, $\mathrm{PID}$ パラメータでは $\mathrm{P}=3.6, \mathrm{I}=33.0, \mathrm{D}=24.0$ と なり，この組み合わせが外気温の変化に強いことになる。 
表 $4 \mathrm{SN}$ 比の計算結果 $[\mathrm{db}]$

Table 4. Result of Computing the $\mathrm{S} / \mathrm{N}$ Ratio [db].

\begin{tabular}{|c||c|c|c|c|c|c|c|c|}
\hline \multicolumn{1}{|c||}{} & \multicolumn{8}{|c|}{ Control Factors } \\
\cline { 2 - 9 } & A: e & B: e & C: P & D: e & E: I & F: e & G: D & H: e \\
\hline \hline 1 & -0.46 & -0.10 & -1.27 & -0.10 & $\mathbf{1 . 8 8}$ & 0.14 & 0.20 & 0.08 \\
\hline 2 & 0.46 & -0.63 & 0.28 & -0.17 & 1.28 & -1.08 & $\mathbf{0 . 2 4}$ & -0.14 \\
\hline 3 & - & 0.74 & $\mathbf{0 . 9 9}$ & 0.26 & -3.16 & 0.94 & -0.45 & 0.05 \\
\hline
\end{tabular}

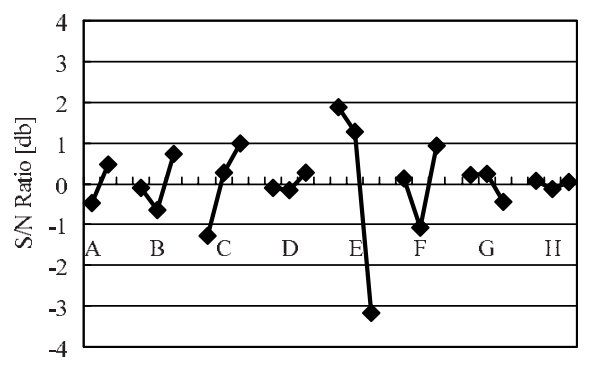

図 10 要因効果図

Fig. 10. Graph of Factorial effects.

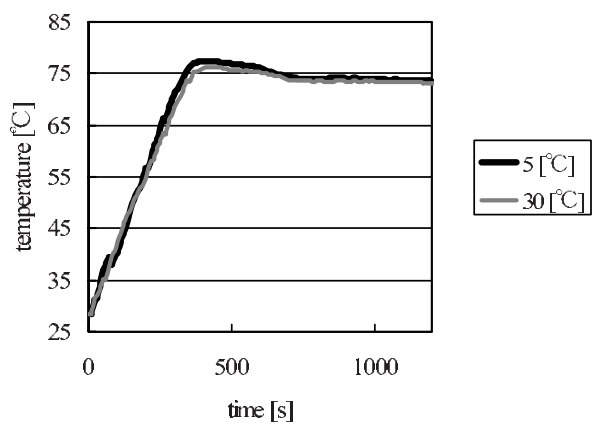

図 11 タグチメソッドによる出力波形

Fig. 11. Output Signals (Taguchi's Robust Design Method).

次に, 求められたPID パラメータがどれだけ外気温の変 化に強いかを確認するための実験を行った。実験方法は直 交表実験と同様に，外気温 $5,30\left[{ }^{\circ} \mathrm{C}\right]$ の 2 条件で，制御用 温度センサ部 $70\left[{ }^{\circ} \mathrm{C}\right]$ に被加熱物を制御したときの観測信 号の波形を比較する。タグチメソッドによる PID パラメー 夕の出力波形を図 11 に示し, 同様にリミットサイクル法で の出力波形を図 12 に示す。この結果から，タグチメソッ ド手法では外気温 $5\left[{ }^{\circ} \mathrm{C}\right]$ と $30\left[{ }^{\circ} \mathrm{C}\right]$ の波形は定常時平均し て $0.3\left[{ }^{\circ} \mathrm{C}\right]$ と多少の違いはあるものの非常に似た波形を示 している。それに対して，リミットサイクル法の波形は定 常時平均して $2.4\left[{ }^{\circ} \mathrm{C}\right]$ とタグチメソッドによる方法に対し て大きな違いが見られる。

また, 本研究で提案したIAEによる制御性能の評価結果 を図 13 に示す。リミットサイクル法による IAE は，外気 温 5，30 [ $\left.{ }^{\circ} \mathrm{C}\right]$ の場合にそれぞれ 371.1，564.6 となってい る。それに対してタグチメソッドによる方法では, 外気温 5, $30\left[{ }^{\circ} \mathrm{C}\right]$ においてそれぞれ 189.8，284.4であり，リミッ トサイクル法より小さいことが分かる。また, 外気温 $5\left[{ }^{\circ} \mathrm{C}\right]$ と $30\left[{ }^{\circ} \mathrm{C}\right]$ の IAE の差, つまり外気温の変化に対するロバ

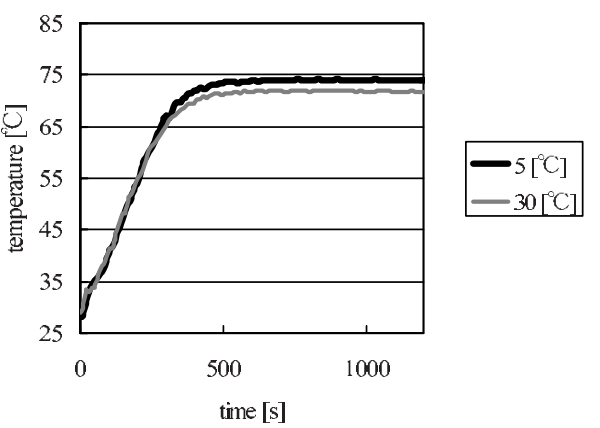

図 12 リミットサイクル法による出力波形

Fig. 12. Output Signals (Limit Cycle Method).

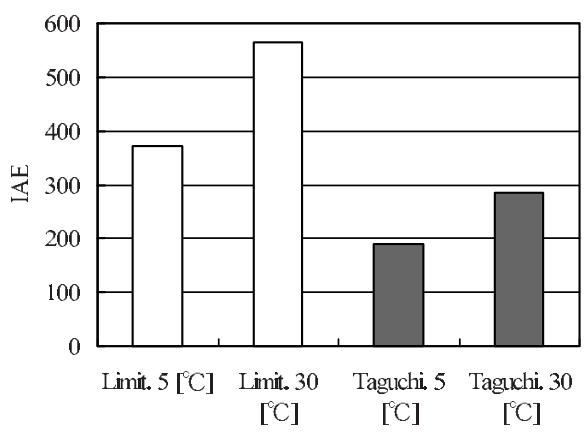

図 13 リミットサイクル法とタグチメソッドの IAE の比較 $(0-1,200[\mathrm{~s}])$

Fig. 13. Comparison of IAE (0-1,200 [s]), Limit Cycle Method and Taguchi's Robust Design Method.

スト性を見ても，リミットサイクル法の 193.5 に対して, タグチメソッドによる方法は 94.6 であり, 100 近くも小さ いことが分かる。なお，本研究の IAE は 0 [s]-1,200 [s] ま での積算值である。

以上のように，制御パラメータ設計にタグチメソッドを 利用することで, 外気温の変化に強い組み込み温度制御シ ステムが得られることが確認できた。

\section{5. おわりに}

本研究では, 外気温の变化に強い組み込み温度制御シス テムの制御パラメータ設計にタグチメソッドの適用法を提 案し, 実機による実験によってその効果を確認した。提案 手法は, 外気温変化のような外乱に対してロバストな制御 性能を得ることを目的としたパラメー夕設計法であるので, 温度制御システム以外にも様々な環境下で使用されること が想定される組み込みシステムにおいて, 種々の応用が可 能であると考えられる。

今後の研究課題としては, PID 制御よりパラメータ数が 多くチューニングの困難な一般の制御則に適用し，性能の 向上を目指すことや，コストに影響を与えないハードウェ アの情報 (センサの位置など) を設計パラメータに追加して ロバスト性を向上させることなどが考えられる。また, 応 用分野を広げるという観点から温度制御以外の種々の制御 システムへの適用も重要である。 
提案手法の特徵は実験結果を利用する設計手法である夕 グチメソッドを制御系の設計に適用するものであり，直交 表に割り付けた制御因子のロバストな組み合わせを求める ものである。これらの組み合わせは，直交表に割り付けた 3 水準の離散的なパラメータの組み合わせであるので，水 準数を増やすことでよりピークに近い組み合わせを求める 設計手法の研究や一般に広く研究されているモデルベース のロバスト制御（例えば $H \infty$ 制御など）との性能比較も今 後の重要な課題と考えている。

(平成 17 年 11 月 24 日受付，平成 18 年 6 月 21 日再受付)

\section{文献}

（1）高田広章他：「リアルタイム OS と組み込み技術の基礎」, CQ 出版社 (2003)

（2）田口玄一：「品質工学の数理」, 日本規格協会 (1999)

(3) C. Yoshimura, H. Ishikawa, S. Furuta, H. Aoki, and S. Sugiyama: "Development, Strength and Functional Evaluation of Plastic Microneedle Array Fabricated by Injection Molding", IEEJ Trans. SM, Vol.124, No.10, pp.387-392 (2004)

(4) Y. Okada and Y. Kawase: "Optimization of Interior Permanent Magnet Motor by Quality Engineering and Multivariate Analysis", IEEJ Trans. IA, Vol.123, No.12, pp.1516-1522 (2003-12) (in Japanese)

岡田幸弘・河瀬順洋 :「品質工学と多変量解析法による磁石埋め达 み形モー夕の最適設計」, 電学論 D, 123, 12, pp.1516-1522 (2003-12)

( 5 ) Y. Enomoto, M. Kitamura, Y. Motegi, T. Andoh, M. Ochiai, and T. Abukawa: "Study on a New Combination Method and High Efficiency Outer Rotor Type Permanent Magnet Motors", IEEJ Trans. IA, Vol.124, No.6, pp.529-535 (2004-6) (in Japanese)

榎本裕治 · 北村正司 ·茂木康彰 ·安藤隆司 ·落合 誠 ·虬川俊美 : 「新締結方法を採用した外転型磁石モータの小形・高効率化」, 電学 論 D, 124, 6, pp.529-535 (2004-6)

（6）須田信英：「PID 制御，システム制御情報ライブラリー」，朝倉書店 (1992)

（7）重政 隆：「セルフチューニング PID 制御の動向」, システム/制御/情 報, Vol.42, No.1, pp.35-40 (1998)

（8）北森俊行:「I-PD 制御方式の原理と設計法」, システム/制御/情報, Vol.42, No.1, pp.7-17 (1998)

(9) M. Kotaki, T. Yamazaki, T. Matuba, K. Kamimura, and S. Kurosu: "A Tuning Method for PID Controller under Consideration of Changes in Plant Characteristics", Trans. of SICE, Vol.41, No.2, pp.177-179 (2005-2) (in Japanese)

古瀧雅和・山崎敬則・松葉匡彦・神村一幸・黒須 茂：「特性変動分 を考慮に入れた PID コントローラの調整」, 計測自動制御学論, 41, 2, pp.177-179 (2005-2)

(10) Y. Ohta, J. Li, K. Tagawa, and H. Haneda: "Design of PID Controller Satisfying Robust Performances", Trans. of ISCIE, Vol.11, No.1, pp.26-34 (1998-1) (in Japanese) 太田有三・李＼cjkstart静・田川聖治・羽根田博正：「複数のロバスト仕様 をみたす PID 制御器の設計」, システム制御情報学論, 11, 1, pp.26-34 (1998-1)

(11) C.-H. Hsieh, J.-H, Chou, and Y.-J. Wu: "Optimal Takagi-Sugeno Fuzzy Gain-Scheduler Design Using Taguchi-MHGA Method", JSME International Journal Series C, Vol.44, No.1, pp.143-155 (2001-1)

(12) S. Futami, A. Zenri, T. Kaneda, H. Hamamatsu, and T. Tsuji: "Optimal Parameter Design of a Position System Incorporated an Accelaration Feedback", JSPE, pp.1157-1158 (2004) (in Japanese)

二見 茂·善利淳臣・金田武志・浜松 弘・辻 輝生：「加速度制御 を付加した位置決め制御系の最適パラメー夕設計」, 精密工学会春季 大会学術講演会講演論文集, pp.1157-1158 (2004)

(13) J. Ohta and S. Yamamoto: "Database-Driven Tuning of PID Controllers", Trans. of SICE, Vol.40, No.6, pp.664-660 (2004-6) (in Japanese) 太田 純・山本 茂:「PID 制御器のデータベース駆動型チューニン グ」, 計測自動制御学論, 40, 6, pp.664-660 (2004-6)

(14) K. Takao, T. Yamamoto, and T. Hinomoto: "A Design of Memory-Based PID Controllers", Trans. of SICE, Vol.40, No.9, pp.898-905 (2004-9) (in Japanese)

高尾健司・山本 透・雛元孝夫 : 「Memory-Based 型 PID コントロー ラの設計」, 計測自動制御学論, 40, 9, pp.898-905 (2004-9)

（15）大須賀公一・足立修一：「システム制御へのアプローチ」, コロナ社 (1998)

（16）久米昭正 他：「化学·薬学・生物学の技術開発 (品質工学応用講座)」, 日本規格協会 (1999)

鈴 木 新 (正員) 1998 年 3 月和歌山大学卒業。同年 4 月

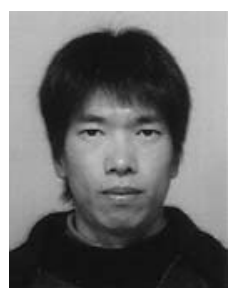
象印マホービン (株) 入社, 現在に至る。2006 年 3 月奈良先端科学技術大学院大学博士後期課程修 了。博士 (工学)。主として, コンピュータ制御シ ステムの設計手法, 品質工学の制御系への応用に 関する研究に従事。システム制御情報学会の会員。

杉 本 謙 二 (非会員) 1982 年 3 月京都大学大学院数理工学

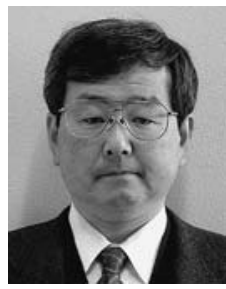
専攻修士課程修了。同年 4 月三菱電機（株）入社。 1985 年 7 月京都大学工学部数理工学科助手, 1989 年 10 月岡山大学工学部情報工学科助教授，1995 年 5 月名古屋大学大学院工学研究科助教授, 1999 年 11 月奈良先端科学技術大学院大学情報科学研 究科教授となり現在に至る。線形システムの制御 理論に関する研究に従事。工学博士。1997 年シ ステム制御情報学会論文賞受賞。IEEE，システム制御情報学会，計測 自動制御学会, 電子情報通信学会, 日本航空宇宙学会, 人工知能学会 などの会員。 